\title{
Leucine-Rich Repeat Transmembrane Neuronal Protein 2
}

National Cancer Institute

\section{Source}

National Cancer Institute. Leucine-Rich Repeat Transmembrane Neuronal Protein 2. NCI

Thesaurus. Code C88990.

Leucine-rich repeat transmembrane neuronal protein 2 (516 aa, $\sim 59 \mathrm{kDa}$ ) is encoded by the human LRRTM2 gene. This protein may play a role in nervous system function. 